\title{
Inflation and Monetary Monopoly: Reflections on Australia's Ten-Dollar Note
}

\author{
Ray Evans
}

I

n October 1993 the Reserve Bank of Australia (RBA) issued a new ten-dollar note. Like the five-dollar note issued some twelve months previously, it is made of plastic, is unpleasant to the touch, and has a singularly unattractive design. The same technology will be used to replace the 20-, 50- and 100-dollar notes in due course. Allegedly, they will last longer, and be much harder to forge, than the old paper notes.

But even if the claims made for the new notes are true, no private supplier of such a product, competing for market share, could have succeeded in persuading the public to use it. Only a monopoly supplier of bank notes could have got away with producing something so widely disdained. Yet this monopolistic character of the money supply, maintained by the state for political and revenue purposes, is assumed to be immutable.

\section{The Great Inflation, 1975-94}

It is nearly 20 years since Friedrich Hayek proposed, almost as an aside, that government monopoly in money supply should be overturned in order to bring inflation to an end.

The politician, acting on a modified Keynesian maxim that in the long run we are all out of office, does not care if his successful cure of unemployment is bound to produce more unemployment in the future. The politicians who will be blamed for it will not be those who created the inflation but those who stopped it. . . Our only hope for a stable money is indeed now to find a way to protect money from politics. (Hayek, 1976:16)

On the effects of the adoption of the proposal [allowing free trade in money and thus enabling banks to issue their own currencyl all I will add at this point is that it is of course intended to prevent national monetary and financial authorities from doing many things politically impossible to avoid so long as they have the power to do them. These are without exception 
harmful and against the long-run interest of the country doing them but politically inevitable as a temporary escape from acute difficulties. (Hayek, 1978:24-5; emphasis added)

After Hayek wrote those words, inflation continued more or less unabated, until the post-1987 recession, compounded by some central banks, began to bite deep in the early 1990 s.

Consider the history of money since US President Richard Nixon, who, in closing the gold window in 1971, revealed the deep contradictions embedded within the post-war Bretton Woods system. Table 1 sets out the half-life of the currencies of 23 industrialised and industrialising countries, over three periods: 1975-82, 198389 and 1990-93. These periods select themselves as the OPEC oil-shock period (with the alleged inflationary effects of large oil-price increases), the Reagan boom, and the post-1987 crash disinflation.

The concept of a currency half-life is useful if the period of calculation does exhibit some uniformity. New Zealand is interesting in this respect. The first period more or less coincides with the era of Prime Minister Robert Muldoon, when New Zealand had one of the shortest half-lives of any currency (5.6 years). The second period was dominated by Finance Minister Roger Douglas's rapid reforms, including the passage of the New Zealand Reserve Bank Act of 1989. In 1991 the fight against inflation unexpectedly began to bear fruit and the country suddenly acquired one of the world's strongest currencies with a half-life of nearly 26 years. (A really good currency would have a half-life of at least a century.)

The Bundesbank is arguably the world's most famous and respected central bank, and its record is the outstanding example of the unavoidable relationship between monopoly supply and sovereign risk. The three half-life figures for Germany given in Table 1 are 17.0, 45.6, and a disastrous 6.3 years. This last figure is the result of the notorious one-for-one policy (one Deutschmark for one Ostmark) imposed by Chancellor Kohl, in the face of strong Bundesbank opposition, when reunification took place in 1991 .

Australia's history resembles New Zealand's, with half-lives of 7.4, 10.8 and, most recently, 21.4 years. But, unlike New Zealand, the markets do not believe that Australia's monetary institutions can hold to a low-inflation course. Although the federal government and the incumbent Governor of the RBA are (at the time of writing) dismissive of market sentiment, other RBA (or ex-RBA) people are less confident. Former Deputy Governor John Phillips drove the point home when he said in a radio interview on 18 October 1990. 'Prices in Australia in the past two decades ... have increased by about five times. .. In that two decades we have had only one year in which the inflation rate, as measured by the Consumer Price Index, was under 5 per cent per annum. I personally don't find that a performance that, as a central banker, I am very proud of.' 


\section{Table 1}

The inflation ladder: currency half-lives of 23 countries, 1975-93

\begin{tabular}{lr}
\multicolumn{2}{c}{$1975-82$} \\
Switzerland & 21.0 \\
Singapore & 19.3 \\
Germany & 17.0 \\
Malaysia & 15.1 \\
India & 13.9 \\
Austria & 13.7 \\
Japan & 12.3 \\
Netherlands & 12.1 \\
Hong Kong & 9.5 \\
USA & 9.3 \\
Thailand & 9.1 \\
Canada & 8.4 \\
Pakistan & 8.0 \\
Sweden & 7.9 \\
Australia & 7.4 \\
France & 7.4 \\
Philippines & 7.2 \\
South Africa & 6.5 \\
UK & 5.8 \\
Indonesia & 5.8 \\
NZ & 5.6 \\
Italy & 5.1 \\
Korea & 4.9
\end{tabular}

1983-89

Singapore $\quad 76.9$

Netherlands 59.2

Japan $\quad 57.1$

Germany $\quad 45.6$

Malaysia $\quad 42.3$

Switzerland 33.9

Austria $\quad 28.5$

Thailand 27.4

USA $\quad 22.2$

Korea $\quad 21.2$

Canada $\quad 17.9$

France $\quad 16.4$

UK $\quad 15.9$

Pakistan 13.3

Sweden $\quad 12.8$

Hong Kong 12.1

Australia $\quad 10.8$

Italy $\quad 10.3$

Indonesia $\quad 10.3$

India $\quad 9.8$

NZ $\quad 8.4$

Philippines $\quad 5.9$

South Africa $\quad 5.8$
$1990-93$

Switzerland 55.3

Japan $\quad 30.2$

$\mathrm{NZ} \quad 25.7$

France : 25.3

Singapore 24.5

Netherlands 22.9

Australia $\quad 21.4$

Canada $\quad 20.5$

Austria $\quad 19.7$

USA $\quad 18.1$

Malaysia $\quad 17.9$

UK $\quad 13.9$

Italy $\quad 12.5$

Sweden $\quad 10.8$

Korea $\quad 9.9$

Indonesia 8.5

Hong Kong 7.4

Pakistan $\quad 7.4$

India $\quad 7.3$

Thailand $\quad 6.4$

Germany $\quad 6.3$

Philippines $\quad 6.1$

South Africa $\quad 5.5$

Source: Intemational Monetary Fund (1993). 


\section{Australia's Experience of Free Banking}

Monetary historians suggest that the great burst in world trade and production that took place after the 1850 s was due in part to the inflationary pressures that followed the great gold discoveries in California and then in eastern Australia. Activity then declined to a small degree, and the period from the 1870 s to the mid-1890s was described by contemporaries as the 'Great Depression'. This relative decline is often ascribed to the decline in gold production between the petering out of the $1850 \mathrm{~s}$ eastern Australian gold discoveries and the new discoveries in South Africa and western Australia of the late 1880s and early 1890s. However, Kevin Dowd (in a private communication) has argued that the demonetisation of silver that took place over this period is at least as important as the absence of new gold discoveries.

Australia at this time was enjoying a period of free banking. The banking industry was freely contestable and stable. Because of the gold rule, inflation was unknown. Banks issued their own notes, and operated a note clearing house (some fine collections of these notes still exist). Even the least aesthetically sophisticated of them is far superior to the new ten-dollar RBA production. Bank notes were redeemable in gold on demand. A number of localised and relatively unimportant bank runs occurred before the devastating banking crashes of the early 1890s. (In my view, the Victorian bank crashes of the 1890 s are entirely due to massive overborrowing on the London market by the Victorian government during the $1880 \mathrm{~s}$, mostly for gold-plated railway construction. Following the Baring Bros collapse in London, these funds dried up, with predictable consequences.) These collapses, nevertheless, prepared the political ground for the monopolisation, by the Commonwealth government, of the note issue by means of the 1910 Commonwealth Bank Notes Act and the establishment of the Commonwealth Bank.

The Australian experience with free banking, which lasted from the 1830 s until 1910 , is one of a number of important historical examples demonstrating that a government monopoly over the money supply is not necessary for monetary or banking stability. Following Hayek's proposals in the 1970s, there has been a major rediscovery of the Scottish, Canadian, Chinese and American periods of more or less free banking and the literature is growing rapidly. Nowadays, virtually no respectable economist is prepared to argue that a state monopoly of the money supply is necessary for banking stability.

Australia in the 19th century was a major gold producer, and under the colonial monetary regime there was no possibility of controlling the quantity of base money that entered the economy: gold and money were one and the same thing. (I should add that until France hastened the process of demonetising silver in the 1870s, the mining and smelting of silver was also equivalent to printing money.) Broken Hill began its life as a silver mine, but by the end of the 1880s silver had been effectively demonetised and fell to nearly half its 1870 value. This in turn led to the attempt to remonetise silver in the US, and to William Jennings Bryan's great nominating speech, in Chicago, at the 1896 Democratic convention, which climaxed with the immortal line: 'Thou shalt not crucify mankind upon a cross of gold'. 
At that time, then, Australia operated under a monetary price rule. The pound sterling was worth 113 grains of gold (7.32 grams) as defined (as the result of an arithmetical error) by $\mathrm{Sir}$ Isaac Newton in 1717 . ( 1 troy oz $=480$ grains $=31.1$ grams.) Where there is no monopoly of note issue, a price rule is the only practicable regime. The manufacture and supply of rulers and measuring tapes, micrometers, and so on, is freely contestable, but works only because there is universal agreement on the length of the inch, the foot, and the metre.

When central banking and monopoly note issue became commonplace, the idea of quantity control made sense. Under monopoly conditions of money supply, the monopolist could conceivably measure and control the amount of money in circulation (at least notes and coins) and thus control the price level. This quantity theory goes back to the 18th-century English philosopher David Hume; and David Glasner's (1989) book on the debate between Hume and Smith is an illuminating piece of work.

\section{Central-Bank Independence, Monetary Discretion, and Political Risk}

The debate between the advocates and opponents of state monopoly is now turning on the New Zealand Reserve Bank and its Act of 1989. The argument is that if we give the central bank independence, a single purpose in life (0-2 per cent inflation), and appoint governors of the strength of character and public spiritedness of the present incumbent, Dr Don Brash, then all will be well. He will succeed where the Bundesbank has failed. However, one can never escape the problem of monopoly supply, which is the discretion that the monopolist, by definition, can never give up. And it is that discretion, bestowed by the politicians upon the central bank, that brings monetary policy into the centre of political life, and inevitably casts the shadow of sovereign risk over the currencies issued by central banks.

The fundamental purpose of a central bank is to exercise monetary discretion, formally in the interests of the general community. However, when we look at even the very best central banks, it seems impossible for governments to refrain from seeking to exercise the central bank's discretion. Governments are, after all, the final repository of responsibility. They have to go the polls; the central bank does not. Hence Australian Prime Minister Keating's justly famous remark concerning the RBA: 'They do what I say'.

The outward and visible signs of the political risk attached to the money issued by a central bank with a statutory monopoly are the yield curve and its gyrations, and the volatility and unpredictability of exchange rates. The advocates of state monopoly, when pressed, will concede the nature of the problem, but their response, apart from appeals to political impossibility, is to accuse the antimonopolists of having failed to come up with a practical and appealing price rule that would make possible competition in money supply, within a particular jurisdiction. It is one thing to define a foot or a gallon, or a metre, or a litre, they say, but another thing to formulate a definition of the Australian dollar that is widely acceptable and free from political interference, and so usher in a golden age of zero infla- 
tion, stable and flat yield curves, and interest rates based only on the time preferences of the people as a whole.

This argument cannot be brushed aside. We have a monopoly central bank, with board members, governors, deputy governors, very nice offices, and the rest. It works, albeit very badly. Attempts to dismantle the institution will not get very far until we come up with a price for the Australian dollar.

\section{The Currency Board Option}

Fixing a price for a local currency need not involve withdrawing the monopolist's privileges, at least in the first instance. A currency board is a monopoly supplier, but it issues notes that are fixed in value with respect to a metropolitan currency. Hong Kong recovered very quickly from a major currency crisis in September 1983 by pegging the HK dollar at the rate of 7.8 to the US dollar and providing 100 per cent backing for the note issue. The Bank of England was, for a very long time, a de facto monopoly issuer of currency that was redeemable, on demand, in gold. Its monopoly position resulted in crises in 1847, 1857, and 1866, but the Bank survived them, albeit with the aid of a friendly Chancellor of the Exchequer, who wrote (or promised to write) letters to the Governor of the Bank promising immunity from prosecution if the Bank exceeded its statutorily required marginal reserve requirement.

Australia could turn its Reserve Bank into a currency board and fix the Australian dollar at, say, 70 US cents. Our interest rates would then track US rates, and there would be no scope for discretionary monetary policy. Because of our dependency on commodities for export income and because commodities are very volatile in price, we would have to learn to accept much more flexible wages, that is, wages that could move with the commodity cycle. Our present labour-market arrangements render that somewhat unlikely. We appear to accept mass unemployment and underemployment far more readily than the idea of flexible wages, even with a fluctuating exchange rate that acts, in some measure, as a shock absorber in the commodity cycle.

Commodity producers, already subject to very large income swings, would have to be able to handle much larger ones. Swings in incomes result in greatly amplified swings in operating surplus and even more magnified swings in share price. There is a real problem, therefore, for commodity producers operating in an environment where the domestic currency is tied, irrevocably, to a metropolitan currency such as the US dollar. This proved to be the case in Chile soon after the Pinochet regime took over in 1973. Soon after Chile tied itself to the US dollar, the latter appreciated, disastrously from the Chilean point of view, against all other major currencies.

Instead of setting the price of the Australian dollar in US cents, we could set it in terms of gold, say, 500 Australian dollars to the ounce. Redeemability would be required, if not in gold itself, then in an outside currency such as US dollars connected through the gold price to gold.

It is easy to smile at an employee of a major gold-mining company arguing for a currency based on gold. Yet from a political point of view, it is beyond argument 
that the Australian people would accept a gold-based currency much more readily than any other definition of the price of the dollar. Gold has been more stable than the US dollar over the last decade. Nevertheless, a significant argument against gold (in Australia's case) is the very large quantities stored in central-bank vaults: some 40,000 tonnes, when annual world production is approximately 2000 tonnes. The US could fix the US dollar to gold and not have to worry about the buying power of these central banks, but Australia is not in the same league.

If gold, for whatever reason, is not acceptable as a pricing mechanism, why not two or more metals? Why not bundle gold and silver together (perhaps William Jennings Bryan was right after all?). If gold and silver together will not suffice, we could go to the basket of commodities, notably the so-called ANCAP basket of ammonium nitrate, plywood, and so on, proposed by Robert Hall (1982). Since direct redeemability of notes with these commodities is impractical, indirect redeemability would have to be accepted. But this need not be a problem, provided some outside form of money is available such as the US dollar or, ultimately, gold.

\section{Commodity Baskets and Indirect Redeemability}

Kevin Dowd $(1990,1994)$ has taken up this problem of commodity baskets and the feedbacks involved when selecting a particular basket that must influence, in unpredictable ways, the production and marketing of the particular commodities selected. The largest commodity basket available to us is the Consumer Price Index (CPI). Every quarter a new measurement is taken of changes in the CPI and the results become part of our official inflation history. Domestic labour costs are fed directly into the CPI by the inclusion of many services, such as haircuts.

How could the CPI be used to set the price of the dollar and provide us with zero inflation money, year in, year out? Dowd assumes a monopoly supplier, a central bank, which is, however, required to redeem its issue, on demand, with a new kind of financial paper. If a holder of notes or deposits becomes suspicious of the central bank's activities, he or she can immediately demand, in exchange for notes or equivalent, an IOU payable, say, in three months' time, which is worth the deposit compounded by an appropriate interest rate (the London Inter-Bank Offered Rate, or LIBOR, for example) and then multiplied by the forthcoming increase in the CPI to be announced during the ensuing quarter. Provided this IOU were not transferable, any fear of inflation would lead to a contraction in bank notes and deposits. If the RBA counterattacked, for example by reducing overnight interest rates, a further flight to Dowd paper (as we may call these certificates) would ensue. Such a mechanism would provides a negative feedback system on the money supply that would will place heavy constraints on the central bank. The system would be virtually identical to the Bank of England operating under a gold rule, with changes in the CPI replacing gold as the disciplinary force on the central bank. Interest-rate manipulation would no longer be required and would certainly not be desired.

Now, it is immediately apparent that a monopoly role for a central bank is unnecessary under his scheme, and the monopoly problem certainly gives rise to in- 
stability. Any bank could issue its own notes under Dowd's redemption requirement; and a system of competitive note issue is much more stable than a system of monopoly note issue, as the crises that occurred under the Bank of England's gold regime in 1847,1857 and 1866 demonstrate. What does become very important is the accuracy and integrity of the process of gathering and releasing CPI information.

Substantial sums would be made or lost on speculation concerning CPI movements. Considerable care would have to be given to the institutional structure and rules governing bodies such as the Australian Bureau of Statistics, which perhaps could be privatised and the industry made contestable.

A dollar that is defined in terms of the largest basket of goods and services we have would not be nearly as subject to changes in the world prices of the particular commodities that Australia exports as our present dollar. (We should not forget, however, that relative interest rates are the biggest factor in exchange-rate risk and fluctuation.)

\section{Conclusion}

In my view, Kevin Dowd has come up with a pricing regime that is practical, theoretically sound, generally understandable and politically sellable. It poses a problem for partisans of central-bank discretion along the lines of the New Zealand Reserve Bank. Inflationary expectations are currently low, and debate is now focusing on upward pressures on the exchange rate. How long that will last no one can tell. It would be an easy thing now to introduce a Dowd IOU based on CPI movements and LIBOR interest rates, and very simple to make such instruments payable on demand. The next step would be to demonopolise the Reserve Bank. This would bring an end to the issuing of distasteful plastic banknotes.

\section{References}

Butlin, S. (1986), The Australian Monetary System, 1851-1914, Judith F. Butin, Sydney.

Dowd, K. (1990), 'Ending Australia's Inflation: The Need for Radical Monetary Reform', Policy 6(3): 1517.

- (1994), 'A Proposal to Fnd Inflation', The Economic Joumal 104(425): 82840.

Glasner, D. (1989), Free Banking and Monetary Reform, Cambridge University Press, Cambridge.

Hall, R. (1982), 'Explorations in the Gold Standard and Related Policies for Stabilising the Dollar', in R. Hall (ed.), Inflation: Causes and Effects, Chicago University Press, London and Chicago.

Hayek, F. (1976), Choice in Currency, Institute of Economic Affairs, London.

- (1978), Denationalisation of Money - The Argument Refined, Instiute of Economic Affairs, London.

International Monetary Fund (1993), Intemational Financial Statistics Yearbook, Washington, D.C. 